\title{
Water use efficiency and economic return of fresh vegetable in organic cultivation
}

\author{
Daniel F. de Carvalho ${ }^{1}$, Marinaldo F. Pinto ${ }^{1}$, José A. Monte ${ }^{2}$, \\ Gabriel A. B. de Mello ${ }^{3}$ \& Camila P. de Sousa ${ }^{1}$ \\ ${ }^{1}$ Universidade Federal Rural do Rio de Janeiro/Instituto de Tecnologia/Departamento de Engenharia. Seropédica, RJ. E-mail: carvalho@ufrrj.br (Corresponding \\ author); mfpufrrj@yahoo.com.br; camilafepi@hotmail.com \\ ${ }^{2}$ Escola Estadual Dom Daniel Comboni. Nova Venécia, ES. E-mail: jam1agr@yahoo.com.br \\ ${ }^{3}$ Universidade Federal Rural do Rio de Janeiro/Instituto de Agronomia. Seropédica, RJ. E-mail: gabrirjrural@gmail.com
}

\section{Key words:}

economic analysis

production functions

analysis of costs

irrigation depth

\begin{abstract}
A B S T R A C T
The optimization in the use of irrigation is a necessity due to water scarcity and the increasing demand for food. The objective of this study was to evaluate the effect of different irrigation depths on the economic efficiency of lettuce, eggplant, beet and carrot, cultivated in an organic production system. The evaluations were performed based on production functions obtained in field experiments conducted from 2006 to 2011, and survey of prices of products and inputs, determining the irrigation depths corresponding to the maximum gross profit and the maximum water use efficiency. Additionally, the relative yield reduction was evaluated for different percent increments in the economically optimal irrigation depth. It was observed that the crops have differences between the irrigation depths of maximum economic efficiency and maximum water use efficiency, ranging from $22.2 \mathrm{~mm}$ (lettuce) to $149.7 \mathrm{~mm}$ (eggplant). The application of water above the irrigation depth of maximum economic efficiency led to yield and profit reductions, whose magnitude depends on the response of the crop.
\end{abstract}

\section{Palavras-chave:}

análise econômica funções de produção análise de custos lâmina de irrigação

\section{Eficiência de uso da água e rendimento econômico no cultivo orgânico de olerícolas}

\begin{abstract}
R E S U M O
A otimização do uso da irrigação é uma necessidade em virtude da escassez de água e do aumento da demanda por alimentos. Objetivou-se, neste trabalho, avaliar o efeito de diferentes lâminas de irrigação sobre a eficiência econômica dos cultivos da alface, berinjela, beterraba e cenoura conduzidas em sistema orgânico de produção. As avaliações foram realizadas com base em funções de produção obtidas em experimentos de campo conduzidos de 2006 a 2011 e no levantamento de preços dos produtos e de insumos determinando-se as lâminas correspondentes ao máximo lucro bruto e à máxima eficiência no uso da água. Adicionalmente, avaliou-se a redução relativa da produtividade para diferentes incrementos percentuais na lâmina economicamente ótima. Observou-se que as culturas apresentam diferenças entre as lâminas de máxima eficiência econômica e do uso da água variando de 22,2 mm (alface) a 149,7 mm (berinjela). A aplicação de água em quantidade superior à lâmina de máxima eficiência econômica proporcionou redução da produtividade e do lucro cuja magnitude depende da resposta da cultura.
\end{abstract}




\section{INTRODUCTION}

Organic agriculture is characterized as a solution to reduce the environmental impacts of the activity (Meier et al., 2015) and, due to the increasing demand of consumers and the obtained yield levels, the commercialization of organic products reached the value of 45 billion Euros in 2013 (Marian et al., 2014).

Since water is a limiting factor for agricultural development and given the increase in the global demand for food, the optimization of its use in irrigation becomes essential for agriculture (Batista et al., 2013), especially because it is one of the sectors most harmed by water scarcity, both quantitatively and qualitatively (Brito et al., 2012).

The search for higher water use efficiency (WUE) in agriculture (Liu \& Stützel, 2004) has played an important role in the formulation of strategies aiming to increase agricultural production without increasing water consumption. However, this indicator should not be used in isolation to define the optimal irrigation depth, because it does not consider production costs or the final value of the product in the market, besides other limiting factors, such as land and capital (Frizzone et al., 2005). Thus, in order to obtain the most adequate irrigation depth to be applied, it is necessary to know the production function of the crop, production costs and market prices.

Based on the above, this study aimed to evaluate the effect of different irrigation depths on water use efficiency and economic yield of lettuce, eggplant, beet and carrot cultivated in an organic production system.

\section{Material ANd Methods}

This study was based on results of experiments conducted from 2006 to 2011 at the SIPA (Integrated Agroecological Production System), located in the municipality of SeropédicaRJ, Brazil (22。 48' 00" S; 434' 00” W; $33.0 \mathrm{~m}$ ). The soil in the region is classified as Red-Yellow Argisol and the climate is Aw according to Köppen's classification.

The crop production functions used in the study were obtained through regression analyses between yield (dependent variable) and irrigation depths (independent variable) for lettuce (Lima et al., 2009), carrot (Oliveira Neto, 2013), beet (Carvalho et al., 2011) and eggplant (Lima et al., 2012). For carrot, two cultivation periods were evaluated: period 1 (June to September 2010 - cycle of 89 days) and period 2 (August to November 2011 - cycle of 93 days). For the other crops, the cultivation periods were from July to November 2007 (cycle of 147 days), June to August 2006 (cycle of 36 days) and June to September 2008 (cycle of 80 days), respectively, for eggplant, lettuce and beet. All production functions were described by second-degree polynomial models, according to Eqs. 1 to 5, subjected to the following restrictions: $70 \leq \mathrm{w} \leq 150 ; 60 \leq \mathrm{w} \leq$ $290 ; 120 \leq \mathrm{w} \leq 355 ; 80 \leq \mathrm{w} \leq 280 ; 350 \leq \mathrm{w} \leq 750$, respectively.

$$
\begin{gathered}
\mathrm{y}_{\mathrm{lt}}=13.302 \mathrm{w}^{2}+3242.3 \mathrm{w}-147654 \\
\mathrm{y}_{\mathrm{crl}}=-1.3845 \mathrm{w}^{2}+609.13 \mathrm{w}-18569
\end{gathered}
$$

$$
\begin{gathered}
\mathrm{y}_{\mathrm{cr} 2}=-1.2884 \mathrm{w}^{2}+735.16 \mathrm{w}-46242 \\
\mathrm{y}_{\mathrm{bt}}=-1.2502 \mathrm{w}^{2}+476.32 \mathrm{w}-12791 \\
\mathrm{y}_{\text {eg }}=-0.59118 \mathrm{w}^{2}+534.6851 \mathrm{w}-54111
\end{gathered}
$$

where:

$\mathrm{y}_{\mathrm{lt}}$ - lettuce yield, $\mathrm{kg} \mathrm{ha}^{-1}$;

$\mathrm{y}_{\mathrm{cr} 1}$ - carrot yield for period $1, \mathrm{~kg} \mathrm{ha}^{-1}$;

$\mathrm{y}_{\mathrm{cr} 2}$ - carrot yield for period 2, $\mathrm{kg} \mathrm{ha}^{-1}$;

$\mathrm{y}_{\mathrm{bt}}$ - beet yield, $\mathrm{kg} \mathrm{ha}^{-1}$;

$\mathrm{y}_{\text {eg }}$ - eggplant yield, $\mathrm{kg} \mathrm{ha}^{-1}$; and,

$\mathrm{w}$ - irrigation depth applied along the cycle, $\mathrm{mm}$.

The irrigation depths were applied through the conventional sprinkler irrigation for eggplant and lettuce, and through drip irrigation for beet and carrot. Irrigation management was performed based on the estimation of crop evapotranspiration using the Class A pan (lettuce and eggplant) and on the soil water balance using the time-domain reflectometry (TDR) technique (beet and carrot).

The production costs in $\mathrm{R} \$ \mathrm{ha}^{-1}$, referring to labor (Table 1) and other inputs (Table 2), regardless of the adopted irrigation method, were obtained through a survey in the market conducted in 2015 and totaled 3,481, 9,810, 7,207 and 7,362, respectively, for lettuce, eggplant, beet and carrot. The cost of electricity per unit of applied irrigation depth was calculated as $0.68 \mathrm{R} \$ \mathrm{~mm}^{-1} \mathrm{ha}^{-1}$, based on the methodology proposed by Carvalho \& Oliveira (2008), considering a 1.5-hp motor pump operating $8 \mathrm{~h} \mathrm{~d}^{-1}$. The price of the water was not taken into account in this study, because the water used in family farmingbased agricultural systems, which practice organic agriculture, is considered as insignificant and, therefore, free of charge.

The revenues of each crop and each treatment were determined considering the yield and the mean market price obtained in 2015, in commercial establishments that sell organic products. Since the objective of the study was not to analyze the profitability of the crops, but the irrigation depth that promotes maximum WUE and/or maximum profit, the gross profit was considered as the difference between the revenue and the costs (Eq. 6), disregarding the initial investment costs.

$$
\mathrm{GP}_{(\mathrm{i}, \mathrm{w})}=\mathrm{y}_{(\mathrm{i}, \mathrm{w})} \times \mathrm{p}_{(\mathrm{i})}-(\mathrm{PE} \times \mathrm{w}+\mathrm{K})
$$

where:

i - crop;

$\mathrm{GP}_{(\mathrm{i}, \mathrm{w})}$ - annual gross profit of the crop i for the irrigation depth w, R\$ ha-1;

$\mathrm{y}_{(\mathrm{i}, \mathrm{w})}$ - yield of crop i for the irrigation depth $\mathrm{w}, \mathrm{kg} \mathrm{ha}^{-1}$;

$\mathrm{p}_{(\mathrm{i})}$ - price of the product from the crop i for the irrigation depth w, R\$ kg-1;

$\mathrm{K}$ - variable costs independent of the applied irrigation depth, R\$; and,

$\mathrm{PE}$ - price of electricity per unit of irrigation depth, R\$ $\mathrm{mm}^{-1} \mathrm{ha}^{-1}$. 
Table 1. Costs with labor for the crops lettuce, eggplant, beet and carrot in organic production system $\left(\mathrm{R} \$ \mathrm{ha}^{-1}\right)$

\begin{tabular}{|c|c|c|c|c|c|c|c|c|}
\hline \multirow{2}{*}{ Description } & \multicolumn{2}{|c|}{ Lettuce } & \multicolumn{2}{|c|}{ Eggplant } & \multicolumn{2}{|c|}{ Beet } & \multicolumn{2}{|c|}{ Carrot } \\
\hline & Quantity & $\mathbf{R} \$$ & Quantity & R\$ & Quantity & $\mathbf{R} \$$ & Quantity & $\mathbf{R} \$$ \\
\hline Soil sampling (day man) & 1 & 40.0 & 1 & 40.0 & 1 & 40.0 & 1 & 40.0 \\
\hline Sowing (day man) & 2 & 80.0 & 2 & 80.0 & 3 & 120.0 & 20 & 800.0 \\
\hline Irrigation on trays (day man) & 2 & 80.0 & 2.5 & 100.0 & 6.5 & 260.0 & - & - \\
\hline Mowing (hour tractor) & - & - & 1 & 90.0 & - & - & - & - \\
\hline Plowing (hour tractor) & 2 & 180.0 & - & - & 2 & 180.0 & 2 & 180.0 \\
\hline Harrowing (hour tractor) & 2 & 180.0 & - & - & 2 & 180.0 & 2 & 180.0 \\
\hline Preparation of beds (hour tractor) & 2 & 180.0 & - & - & 2 & 180.0 & 2 & 180.0 \\
\hline Opening of holes (day man) & - & - & 10 & 400.0 & - & - & - & - \\
\hline Initial fertilization (day man) & - & - & 10 & 400.0 & 8 & 320.0 & 8 & 320.0 \\
\hline Transplantation (day man) & 20 & 800.0 & 5 & 200.0 & 20 & 800.0 & - & - \\
\hline Irrigation (day man) & 3 & 120.0 & 3 & 120.0 & 3 & 120.0 & 3 & 120.0 \\
\hline Thinning (day man) & - & - & - & - & - & - & 50 & 2000.0 \\
\hline Row weeding (day man) & - & - & 8 & 320.0 & - & - & - & - \\
\hline Interrow mowing (day man) & - & - & 2 & 80.0 & - & - & - & - \\
\hline Top-dressing fertilization (day man) & - & - & 4 & 160.0 & - & - & - & - \\
\hline Harvest (day man) & 20 & 800.0 & 20 & 800.0 & 20 & 800.0 & 25 & 1000.0 \\
\hline Internal transport (day man) & 5 & 200.0 & 4 & 160.0 & 4 & 160.0 & 3 & 120.0 \\
\hline Cleaning/Classification (day man) & 5 & 200.0 & 2 & 80.0 & 4 & 160.0 & 4 & 160.0 \\
\hline Total of labor & \multicolumn{2}{|c|}{$2,860.0$} & \multicolumn{2}{|c|}{$3,030.0$} & \multicolumn{2}{|c|}{$3,320.0$} & \multicolumn{2}{|c|}{$5,100.0$} \\
\hline
\end{tabular}

- does not apply

Table 2. Costs of inputs for the production of lettuce, eggplant, beet and carrot in organic production system (R $\$$ ha $\left.^{-1}\right)$

\begin{tabular}{|c|c|c|c|c|c|c|c|c|}
\hline \multirow{2}{*}{ Description } & \multicolumn{2}{|c|}{ Lettuce } & \multicolumn{2}{|c|}{ Eggplant } & \multicolumn{2}{|c|}{ Beet } & \multicolumn{2}{|c|}{ Carrot } \\
\hline & Quantity & $\mathrm{R} \$$ & Quantity & $\mathbf{R} \$$ & Quantity & $\mathrm{R} \$$ & Quantity & $\mathbf{R} \$$ \\
\hline Substrate $\left(\mathrm{m}^{3}\right)$ & 2.2 & 220.0 & 0.2 & 20.0 & 4 & 400.0 & - & - \\
\hline Seeds (kg) & 3 & 54.0 & 2 & 330.0 & 4 & 428.0 & 4 & 352.0 \\
\hline Bovine manure $(\mathrm{t})$ & - & - & 5.5 & 550.0 & 25 & 2500.0 & 18.6 & 1860.0 \\
\hline Depreciation of utility assets & - & 347.0 & - & 75.0 & - & 559.0 & - & 50.0 \\
\hline Castor bean cake (50-kg sack) & - & - & 20 & 1700.0 & - & - & - & - \\
\hline Bone flour (kg) & - & - & 510 & 4080.0 & - & - & - & - \\
\hline Gasoline (L) & - & - & 8 & 25.0 & - & - & - & - \\
\hline Total of inputs & \multicolumn{2}{|c|}{621.0} & \multicolumn{2}{|c|}{6780.0} & \multicolumn{2}{|c|}{$3,887.0$} & \multicolumn{2}{|c|}{$2,262.0$} \\
\hline
\end{tabular}

- does not apply

Substituting yield $\left(\mathrm{y}_{(\mathrm{i}, \mathrm{w})}\right)$ by the production function as a function of the applied irrigation depth, it follows that:

$$
\mathrm{GP}_{(\mathrm{i}, \mathrm{w})}=\left(\mathrm{a}_{(\mathrm{i})} \mathrm{w}^{2}+\mathrm{b}_{(\mathrm{i})} \mathrm{w}+\mathrm{c}_{(\mathrm{i})}\right) \times \mathrm{p}_{(\mathrm{i})}-(\mathrm{PE} \times \mathrm{w}+\mathrm{K})
$$

where:

$\mathrm{a}_{(\mathrm{i})}, \mathrm{b}_{(\mathrm{i})}$ and $\mathrm{c}_{(\mathrm{i})}$ - adjustment parameters of the yield equation as a function of the irrigation depth, for the crop $i$.

The market prices were $\mathrm{R} \$ 2.18 \mathrm{~kg}^{-1}$ for beet and $\mathrm{R} \$ 2.00$ $\mathrm{kg}^{-1}$ for the other crops considered in the study.

The WUE of each crop was calculated through Eq. 8.

$$
\mathrm{WUE}_{(\mathrm{i}, \mathrm{w})}=\frac{\mathrm{y}_{(\mathrm{i}, \mathrm{w})}}{\mathrm{w}_{(\mathrm{i})}}=\mathrm{a}_{(\mathrm{i})} \mathrm{w}+\mathrm{b}_{(\mathrm{i})}+\frac{\mathrm{c}_{(\mathrm{i})}}{\mathrm{W}}
$$

where:

$\mathrm{WUE}_{(\mathrm{i}, \mathrm{w})}$ - water use efficiency for the crop i and irrigation depth $\mathrm{w}, \mathrm{kg} \mathrm{mm}^{-1} \mathrm{ha}^{-1}$;

$\mathrm{y}_{(\mathrm{i}, \mathrm{w})}$ - yield of the crop i for an irrigation depth w, $\mathrm{kg} \mathrm{ha}^{-1}$.

The irrigation depths that promoted maximum yield $\left(\mathrm{w}_{\mathrm{mY}}\right)$ (Eq. 9), maximum gross profit $\left(\mathrm{w}_{\mathrm{mGP}}\right)$ (Eq. 10) and maximum WUE $\left(\mathrm{w}_{\text {mWUE }}\right)$ (Eq. 11) were obtained through the derivation of their respective functions.

$$
\begin{gathered}
\mathrm{w}_{\mathrm{mY}(\mathrm{i})}=\frac{\mathrm{b}_{(\mathrm{i})}}{2 \mathrm{a}_{(\mathrm{i})}} \\
\mathrm{w}_{\mathrm{mGP}(\mathrm{i})}=\frac{\mathrm{PE}-\mathrm{b}_{(\mathrm{i})} \mathrm{p}_{(\mathrm{i})}}{2 \mathrm{a}_{(\mathrm{i})} \mathrm{p}_{(\mathrm{i})}} \\
\mathrm{w}_{\mathrm{mWUE}(\mathrm{i})}=\sqrt{\frac{\mathrm{c}_{(\mathrm{i})}}{\mathrm{a}_{(\mathrm{i})}}}
\end{gathered}
$$

The optimal irrigation depth for each analyzed crop $\left(\mathrm{w}_{\mathrm{op}(\mathrm{i})}\right)$ was considered as the one that promoted the maximum gross profit, i.e., $\mathrm{w}_{\mathrm{op}(\mathrm{i})}=\mathrm{w}_{\mathrm{mGP}(\mathrm{i})}$. Based on the optimal irrigation depth, yield and gross profit, the variations of yield and gross profit were calculated for increments in the optimal irrigation depth of $5,10,15,20,25$ and $30 \%$. In addition, for each crop, the relationship between optimal irrigation depth and irrigation depths that promote maximum yield and maximum WUE were considered. Variations were expressed in relation to the value obtained for the optimal irrigation depth.

The parameters of the production function may change due to random factors, such as climatic variations, pests and diseases. Thus, variations of -10 to $10 \%$ were simulated for the parameters a and b, by applying the Eq. 10 to the parameters of the production functions presented in Eqs. 1 to 5 and to the 
new values considering the simulated variations. The variation in the optimal irrigation depth was calculated as a function of the value without the variation in the parameters. Regardless of the crop, the variation can be calculated in general terms, according to Eq. 12.

$$
\gamma=\left[1-\frac{P E-\left(1+k_{b}\right) \times b \times p}{\left(1+k_{a}\right)(P E-b \times p)}\right] \times 100
$$

where:

$\gamma$ - percent variation in the optimal irrigation depth, \%;

$\mathrm{k}_{\mathrm{a}}$ and $\mathrm{k}_{\mathrm{b}}$ - variation of the parameters $\mathrm{a}$ and $\mathrm{b}$ of the production function, decimal; and,

$\mathrm{p}$ - price of the product, $\mathrm{R} \$ \mathrm{~kg}^{-1}$.

\section{Results AND Discussion}

Table 3 shows the values of yield and profit relative to the value obtained with optimal irrigation depth for different increments and for the maximum-WUE irrigation depth. Irrigation depths higher than the optimal one lead to reduction in the yield of the crops and the magnitude depends on their sensitivity. Likewise, the net revenue is also reduced, which occurs because water excess affects soil aeration, fertility, due to the leaching of nutrients, and the development of diseases (Frizzone et al., 2005). Thus, the profitability can only decrease considering the increase in the use of inputs and the reduction in yield.

For maximum-WUE irrigation depth, there was a reduction in both yield and profit, which was greater in cases in which there was an excess of water. The greatest reduction in the net revenue was observed for beet and carrot, which showed approximately $30 \%$ of variation in relation to the optimal irrigation depth. On the other hand, for the maximum-WUE irrigation depth, the lowest yield reduction was obtained in lettuce, i.e., this crop could be recommended for regions in which water is a restrictive factor and in which one must opt for maximizing WUE (Souza et al., 2011).

The decision on the irrigation depth to be applied depends on various factors, because, if maximum-Y or maximum-GP irrigation depth is used, there may be a demand of greater water volume for the same amount produced. On the other hand, the use of maximum-WUE irrigation depth implies that a larger cultivation area is used to produce the same amount of food. Hence, in order to obtain an optimal solution, it is necessary to take into account restrictive factors, such as water, land and capital (Frizzone et al., 2005; Figueiredo et al., 2008). In the present study, water was considered as the only restrictive factor, so that the optimal irrigation depth promotes optimal profit per unit of water volume. If land were the restrictive factor, the most adequate procedure would be to search for the maximum profit per unit of area.

A very important issue to be analyzed is the variation in the prices of inputs, products and electricity. Depending on the combination of variation of the prices, the results may be totally different. Another factor is the variation in the parameters of the production curve, as shown in Table 4 . The variations in the optimal irrigation depth are on the order of $\pm 20 \%$, if there is variation of up to $10 \%$ in the parameters a and b. According to Figueiredo et al. (2008), variations in these parameters are related to random factors, such as climatic variations, pests and diseases, subjecting the activity to risks to the revenue or the expected yield (Frizzone, 2004).

For the optimal irrigation depth, the prices of product and electricity have little influence on the results and can be disregarded in the calculations, according to Eq. 12; this is due to the fact that the price of electricity is very low compared with the values of the product and of the parameter $b$.

For all crops, there were no differences between maximumGP and maximum-Y irrigation depths, because the variable cost relative to the applied irrigation depth is of low magnitude; thus, only the cost of electricity was considered. Similar results were reported by Vilas Boas et al. (2008) and Oliveira et al. (2011), who concluded that the economically optimal irrigation depth varies linearly with respect to the prices of water and product.

According to the curves of WUE and GP as a function of the irrigation depth applied for the analyzed crops (Figure 1), it is possible to observe the irrigation depths that promote maximum GP and maximum WUE. Lettuce (Figure 1A) was the crop that showed the closest values of optimal irrigation depth $(131.8 \mathrm{~mm})$

Table 4. Variation in optimal irrigation depth as a function of the variation in production function parameters

\begin{tabular}{cccccc}
\hline & \multicolumn{5}{c}{$\mathbf{k}_{\mathrm{b}}(\mathbf{\%})$} \\
\cline { 2 - 6 } $\mathbf{a}_{\mathrm{a}}(\%)$ & $\mathbf{- 1 0}$ & $\mathbf{- 5}$ & $\mathbf{0}$ & $\mathbf{5}$ & $\mathbf{1 0}$ \\
\cline { 2 - 6 } & \multicolumn{5}{c}{ Variation in optimal irrigation depth (\%) } \\
-10 & 0 & -5.6 & -11.1 & -16.7 & -22.2 \\
-5 & 5.3 & 0 & -5.3 & -10.5 & -15.8 \\
0 & 10 & 5 & 0 & -5 & -10 \\
5 & 14.3 & 9.5 & 4.8 & 0 & -4.8 \\
10 & 18.2 & 13.6 & 9.1 & 4.5 & 0 \\
\hline
\end{tabular}

Table 3. Variation of yield and gross profit as a function of the applied irrigation depth

\begin{tabular}{|c|c|c|c|c|c|c|c|}
\hline Crop & $W_{o p}+5 \%$ & $W_{o p}+10 \%$ & $W_{o p}+15 \%$ & $W_{o p}+20 \%$ & $W_{o p}+25 \%$ & $W_{o p}+30 \%$ & $\mathrm{~W}_{\mathrm{mWUE}}$ \\
\hline \multicolumn{8}{|c|}{ Variation of yield (\%) } \\
\hline Lettuce & -0.8 & -3.2 & -7.3 & - & - & - & -9.2 \\
\hline Carrot1 & -0.3 & -1.4 & -3.1 & -5.5 & -8.6 & -12.4 & -31.0 \\
\hline Carrot2 & -0.4 & -1.8 & -4.0 & -7.1 & -11.1 & - & -20.2 \\
\hline Beet & -0.3 & -1.4 & -3.1 & -5.5 & -8.7 & -12.5 & -30.7 \\
\hline Eggplant & -0.4 & -1.8 & -4.0 & -7.2 & - & - & -19.8 \\
\hline \multicolumn{8}{|c|}{ Variation of gross profit (\%) } \\
\hline Lettuce & -0.8 & -3.3 & -7.5 & - & - & - & -9.4 \\
\hline Carrot1 & -0.4 & -1.5 & -3.4 & -6 & -9.4 & -13.5 & -33.6 \\
\hline Carrot2 & -0.5 & -1.9 & -4.3 & -7.7 & -12.0 & - & -21.5 \\
\hline Beet & -0.4 & -1.6 & -3.5 & -6.2 & -9.7 & -14 & -34.1 \\
\hline Eggplant & -0.5 & -2.0 & -4.4 & -7.8 & - & - & -21.4 \\
\hline
\end{tabular}

$\mathrm{W}_{\mathrm{op}}$ - Optimal irrigation depth; 5, 10, 15, 20, 25 and 30\% - Increments in optimal irrigation depth; - Does not apply 

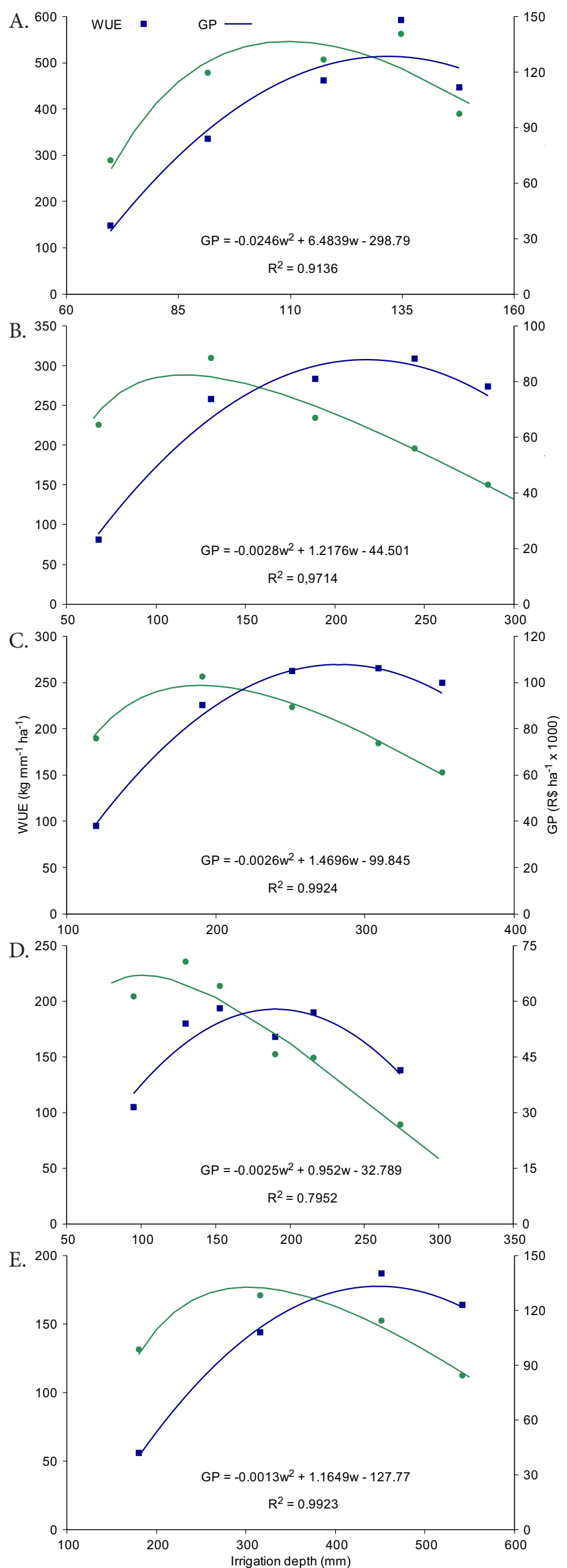

Figure 1. Water use efficiency (WUE) and gross profit (GP) as a function of irrigation depth (w) for the crops: (A) lettuce; (B) carrot 1; (C) carrot 2; (D) beet; (E) eggplant and maximum-WUE irrigation depth $(109.6 \mathrm{~mm})$. On the other hand, the eggplant crop showed the greatest difference between the respective irrigation depths (452.2 and $302.5 \mathrm{~mm}$ ). For beet and carrot, the use of maximum-WUE irrigation depth promotes the greatest reduction in the relative profit, among all evaluated crops (beet: $34.1 \%$; carrot 1: 33.6\%; carrot2: $21.5 \%$ ). It means that, in order to maintain the same income, the farmer would have to increase the planted area, i.e., the search for the increase in WUE does not necessarily promotes reduction in water consumption.

Among the different periods of carrot production, according to Figures $1 \mathrm{~B}$ and $1 \mathrm{C}$ and Table 3, the relative reduction of profit and yield caused by the increment in the applied irrigation depth showed the same order of magnitude, i.e., it can be claimed that the relative reduction expresses the sensitivity of the crop, regardless of the cultivation period.

Besides the economic issue, it is known that the reduction in irrigation depth in relation to crop evapotranspiration is limited by water quality, soil salinity and crop sensitivity to salinity. According to Ayres \& Westcot (1999), carrot and beet crops are, respectively, sensitive and moderately sensitive, while lettuce and eggplant are moderately sensitive, which implies that, except for eggplant, depending on water quality, it would be necessary to apply a leaching fraction in order to maintain the balance in soil solution salinity.

\section{Conclusions}

1. The maximum water use efficiency for the evaluated crops promotes reduction in the gross profit.

2. The use of maximum economic efficiency must be preferred if there is no restriction in the use of water.

3. The application of irrigation depths higher than those promoting maximum profit may lead to losses for the farmer, depending on the increment in irrigation depth.

\section{Literature Cited}

Ayres, R. S.; Westcot, D. W. A qualidade da água na agricultura. Campina Grande: UFPB/FAO, 1999. 153p. Estudos FAO: Irrigação e Drenagem, 29

Batista, S. C. O.; Carvalho, D. F.; Rocha, H. S.; Santos, H. T.; Medici, L.O. Production of automatically watered lettuce with a low cost controller. International Journal of Food, Agriculture and Environment, v.11, p.485-489, 2013.

Brito, R. R.; Gomes, E. R.; Ludwig, R. Uso da água na irrigação. Fórum Ambiental da Alta Paulista, v.8, p.373-383, 2012. http://dx.doi. org/10.17271/19800827822012266

Carvalho, D. F.; Oliveira Neto, D. H.; Ribeiro, R. L. D.; Guerra, J. G. M.; Rouws, J. R. C. Manejo da irrigação associada a coberturas mortas vegetais no cultivo orgânico da beterraba. Engenharia Agrícola, v.31, p.269-277, 2011. http://dx.doi.org/10.1590/ S0100-69162011000200007

Carvalho, J. A.; Oliveira, L. F. C. Instalações de bombeamento para irrigação: Hidráulica e consumo de energia. Lavras: UFLA, 2008. 354p.

Figueiredo, M. G.; Frizzone, J. A.; Pitelli, M. M.; Rezende, R. Lâmina ótima de irrigação do feijoeiro, com restrição de água, em função do nível de aversão ao risco do produtor. Acta Scientiarum Agronomy, v.30, p.81-87, 2008. http://dx.doi.org/10.4025/ actasciagron.v30i1.1135 
Frizzone, J. A. Otimização do uso da água na agricultura irrigada: Perspectivas e desafios. Engenharia Rural, v.15, p.37-56, 2004.

Frizzone, J. A.; Andrade Júnior, A. S.; Souza, J. L. M.; Zocoler, J. L. Planejamento de irrigação: Análise de decisão de investimento. Embrapa Informação Tecnológica, Brasília, 2005. 626p.

Lima, M. E.; Carvalho, D. F.; Souza, A. P.; Guerra, J. G. M.; Ribeiro, R. L. D. Desempenho da alface em cultivo orgânico com e sem cobertura morta e diferentes lâminas d'água. Ciência e Agrotecnologia, v.33, p.1503-1510, 2009. http://dx.doi. org/10.1590/S1413-70542009000600007

Lima, M. E.; Carvalho, D. F.; Souza, A. P.; Rocha, H. S.; Guerra, J. G. M. Desempenho do cultivo da berinjela em plantio direto submetida a diferentes lâminas de irrigação. Revista Brasileira de Engenharia Agrícola e Ambiental, v.16, p.604-610, 2012. http:// dx.doi.org/10.1590/S1415-43662012000600003

Liu, F.; Stützel, H. Biomass partitioning, specific leaf area, and water use efficiency of vegetable amaranth (Amaranthus spp.) in response to drought stress. Scientia Horticulturae, v.102, p.15-27, 2004. http://dx.doi.org/10.1016/j.scienta.2003.11.014

Marian, L.; Chrysochou, P.; Krystallis, A.; Thøgersen, J. The role of price as a product attribute in the organic food context: An exploration based on actual purchase data. Food Quality and Preference, v.37, p.52-60. 2014. http://dx.doi.org/10.1016/j.foodqual.2014.05.001
Meier, M. S.; Stoessel, F.; Jungbluth, N.; Juraske, R.; Schader, C.; Stolze, M. Environmental impacts of organic and conventional agricultural products - Are the differences captured by life cycle assessment? Journal of Environmental Management, v.149, p.193208. 2015. http://dx.doi.org/10.1016/j.jenvman.2014.10.006

Oliveira, E. C.; Carvalho, J. A.; Rezende, F. C. Freitas, W. A. Viabilidade técnica e econômica da produção de ervilha (Pisum sativum L.) cultivada sob diferentes lâminas de irrigação. Engenharia Agrícola, v.31, p.324-333, 2011. http://dx.doi.org/10.1590/S010069162011000200012

Oliveira Neto, D. H. Manejo da água no cultivo da cenoura com uso de coberturas mortas no solo, em sistema agroecológico de produção. Seropédica: UFRRJ, 2013. 76p. Tese Doutorado

Souza, L. S. B.; Moura, M. S. B.; Sediyama, G. C.; Silva, T. G. F. Eficiência do uso da água das culturas do milho e do feijão-caupi sob sistemas de plantio exclusivo e consorciado no semiárido brasileiro. Bragantia, v.70, p.715-721, 2011. http://dx.doi. org/10.1590/S0006-87052011000300030

Vilas Boas, R. C.; Carvalho, J. A.; Gomes, L. A. A.; Sousa, A. M. G.; Rodrigues, R. C.; Souza, K. J. Avaliação técnica e econômica da produção de duas cultivares de alface tipo crespa em função de lâminas de irrigação. Ciência e Agrotecnologia, v.32, p.525-531, 2008. http://dx.doi.org/10.1590/S1413-70542008000200028 